\title{
Developing Framework for Alternative Funding Options in Water Infrastructure Projects
}

\author{
Matt Nafziger ${ }^{1}$, Dan Koo ${ }^{2}$ \\ ${ }^{1}$ Construction Engineering Management Technology Department of Engineering Technology, Purdue School of \\ Engineering and Technology, Indiana University Purdue University Indianapolis (IUPUI), Indianapolis, IN, USA \\ ${ }^{2}$ Construction Engineering Management Technology, Purdue School of Engineering and Technology, Indiana \\ University Purdue University Indianapolis (IUPUI), Indianapolis, IN, USA \\ Email: jnafzige@umail.iu.edu, dankoo@iupui.edu
}

Received 19 February 2015; accepted 13 March 2015; published 17 March 2015

Copyright @ 2015 by authors and Scientific Research Publishing Inc.

This work is licensed under the Creative Commons Attribution International License (CC BY).

http://creativecommons.org/licenses/by/4.0/

(c) (i) Open Access

\section{Abstract}

The United States is facing a crisis in which less financial resources are available to maintain the quality and to meet increasing demand of our water infrastructure system. Water utility owners across the nation are faced with the incredible challenge of finding ways to invest because of limited government funding, from local to federal levels. The funding gap between available and necessary funds has been increasing and expected to increase in the future. With government unable to provide adequate funding, water utility owners should consider alternative funding sources such as private partnerships and investment. There are many key aspects of an effective funding strategy for water utility owners to achieve successful water infrastructure planning and development. This paper presents various funding alternatives and provides a framework for utilizing alternative funding in water infrastructure planning and development to help alleviate funding gaps while simultaneously encouraging future sustainability in public water infrastructure.

\section{Keywords}

Public Private Partnership (PPP), Infrastructure Financing, Water Infrastructure

\section{Introduction}

The crisis of declining infrastructure is prevalent throughout numerous types of infrastructure, and emphasis usually gets placed on those in the public's view on a daily basis, and water infrastructure is often overlooked. 
ASCE's 2013 Report Card, gave both drinking water and wastewater infrastructure a "D”. Capital needs for treatment plants alone cover only $15 \%-20 \%$ of total needs [1]. Water infrastructure can be defined as facilities, equipment and other assets essential to manage water resources. This includes collection, storage, pumping, and any other asset needed to get water to consumers, as well as what is necessary to transport, treat and reuse waste and storm water.

In 2011, a survey was conducted by the Environmental Protection Agency asking community water system owners to estimate their need in order to better understand the future needs of water systems across the country. The survey was used to calculate the estimated 20-year need of drinking water infrastructure funding in different sized communities. The survey found that community drinking water systems serving over 100,000 people could require about $\$ 145.1$ billion dollars during the next twenty years. Water systems serving 3301 to 100,000 people need $\$ 161.8$ billion, while systems serving 3300 or less need $\$ 64.5$ billion. Not-for-profit, Alaskan Native village, American Indian systems, as well as costs imposed by newer regulations were also included, with a total of $\$ 12.8$ billion. The United States Environmental Protection Agency (USEPA) conducted a similar survey in 2008 regarding 20 year wastewater and storm water needs, citing the total need at $\$ 298.1$ billion. $\$ 192.2$ billion is needed for public wastewater pipes and treatment facilities, $\$ 63.6$ billion to address combined sewer overflow issues, and $\$ 43.3$ billion for storm water management [2]. On the other hand, the American Society of Civil Engineers (ASCE) estimated further funding gap at present and for foreseeable future. $\$ 91.2$ billion was needed to fund water and wastewater infrastructure projects in 2010 but only $\$ 36.4$ billion was spent, creating a funding gap of $\$ 54.8$ billion. The report estimates that by 2020, $\$ 125.9$ billion will be needed, raising the gap to $\$ 84.4$ billion. By 2040, the report estimates the funding gap will rise to almost $\$ 144$ billion [3].

With governments unable to provide adequate increase in public capital resources needed to fund growing infrastructure spending needs, federal, state and local governments should look to the private sector for funding. Some municipalities have already utilized private funding in the form of a public private partnership (PPP), but many such projects have not been successful. A Food and Water Watch report highlights some failed attempts at private participation in the United States. In Atlanta, GA, private partners refused to release certain billing records, and built up a backlog of over 14,000 work orders. In Camden, NJ, water loss increased as high as 45\%, and the private partner amassed over \$5 million in unpaid user bills. In Milwaukee, WI, over 20 notices of noncompliance were received regarding sewage overflows before the PPP contract was canceled [4]. These are just a few examples of how public private partnerships can produce negative results if not properly structured and planned. Public perceptions and misunderstandings regarding what went wrong, and why, are often a reason for tension. There are many aspects of an effective strategy for infrastructure improvement, but without proper financial planning the project will not be successful.

According to a survey by a global industry engineering firm, the top three issues of importance in the water and wastewater industry are 1) Aging water and sewer infrastructure; 2) Managing capital costs and 3) Funding and availability of capital. Through careful design and financial planning of infrastructure projects, all three of these issues can be addressed. The same survey also found that $73.8 \%$ of respondents believe that infrastructure replacement and rehabilitation will have a "strong impact" on the financial health of water utilities. The survey also asked utilities how they interpreted their customer's views on water rates. They found that $68.5 \%$ of ratepayers likely have little understanding of the water infrastructure funding gap, but also that almost half (48.3\%) of customers would "probably" be willing to pay increased rates to support the capital spending needed for improvement. Regardless of what method is chosen by a utility to address their infrastructure needs, it is important that their customers are educated about the funding gap, why it exists and why it's growing [5].

This paper presents various funding alternatives and provides a framework for utilizing alternative funding in water infrastructure planning and development to help alleviate funding gaps while simultaneously encouraging future sustainability in public water infrastructure. This can be done by looking at sources of funding currently being most utilized and exploring the benefits of private funding, while showing the different ways it can be implemented.

\section{Current Funding Sources}

The main funding components concerning funding of a water utility or project throughout a life cycle of a water infrastructure system are as shown in Figure 1. Typical planning, design, and initial construction of a project 
Funding Resources

\begin{tabular}{ll|}
\hline - & User Rates \\
- & Lrants and Subsidies \\
- & Municipal Bonds \\
- & Revenue Guarantees \\
- & Other Capital Provision \\
- & Salvage Value of Asset \\
\hline
\end{tabular}

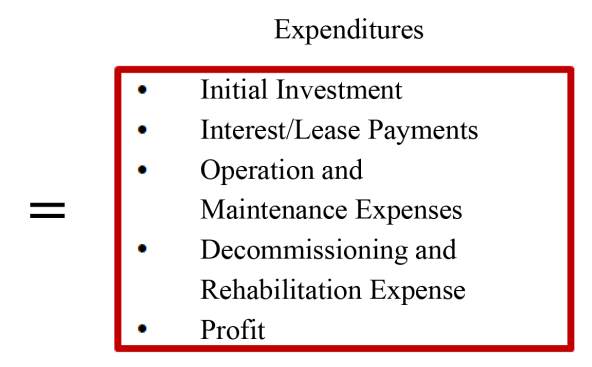

Figure 1. Funding components for a water infrastructure system.

shall be a part of the initial investment. That diagram depicted is not inclusive of everything that is to be taken into account when analyzing financial need, but it can help display several important points.

If any one element on one side of the equation is reduced, it should be made up for on the opposite side. The issue facing utilities currently is that the rehabilitation expense and the capital investment needed for improvement and expansion is simply too high, and to balance the equation, rates and service fees are rising. It is understandable that with increased need for capital, there will likely be increased water utility rates. That is also important to address, so that ratepayers know why their rates are going up, and what the money is actually going towards. Since providing capital and funding to run the utility is only part of the equation, it is important to look at the other part as well. Utilities are well aware that they face a great need for additional funding. Not only do utilities need to address their source of funding, but they need to look into ways to decrease the amount of funding needed. Utility owners should look at alternative sources of funding, mainly private capital, as not only a way to address the funding gap and how to help fill it, but as a tool to decrease the amount of capital actually required for needed water infrastructure improvements and additions.

The options available to them are not quite as easy to ascertain. This issue can be addressed by looking at current sources of funding, as well as ways in which private funding can be used to help address the funding gap. There are four major sources of federal spending on water infrastructure that allocate funds for water infrastructure. They are the United States Environmental Protection Agency’s Clean Water and Drinking Water State Revolving Funds (CWSRF and DWSRF), as well as the United States Department of Agriculture's Rural Utilities Service (RUS) and the United States Department of Housing and Urban Developments Community Development Block Grant (CDBG).

The state revolving funds (DWSRF and CWSRF) are the largest form of government public investment. As indicated in Figure 2, investment through the State Revolving Funds remained between about \$2 to \$3 billion from 1986 to 2008. In 2006, the amount allocated by the USEPA fell under \$2 billion for the first time in over a decade. In 2009 however, there is a large spike in the graph. The American Reinvestment and Recovery Act of 2009 were responsible for an influx of funds for water infrastructure projects. In fact, the funds made available from 2009-2011 are the only reason the trend line shows a positive value. Since 2009, however, the allocations have decreased every year since, and are once again approaching the sub-\$2 billion mark. Even though the long-term decrease has not been severe, it is not satisfactory based on the estimated long-term capital needs to repair and rehabilitate water infrastructure.

In addition to the State Revolving Funds and other government programs, the public can provide funds for infrastructure through municipal bonds. A bond borrows money from a group of investors instead of a single source, but is structured similarly to a loan with an interest rate and repayment schedule. There are various forms of bonds issued, and they are usually sold in a "series" designed for a certain project. General obligation bonds can be used to fund infrastructure projects and can be repaid with any source, including taxation. Revenue bonds are more common for most utilities, and the ratepayers who use the utility repay them through their monthly water bills.

In addition to debt financing such as grants, loans and bonds; cash, mostly that which is raised from ratepayers, can be used to fund infrastructure projects as well. Using cash instead of debt can have a significant impact on rates paid by utility ratepayers. When cash is used, the initial cost of the project is very high and rates almost immediately jump. Debt financing can reduce the initial cost passed on to ratepayers, but can increase it in the long run instead. Debt financing is generally preferred by city and utility managers because of the lower shortterm rates available when compared to the higher rates that need to be charged when cash financing is utilized. 
SRF Allocations 1986-2012

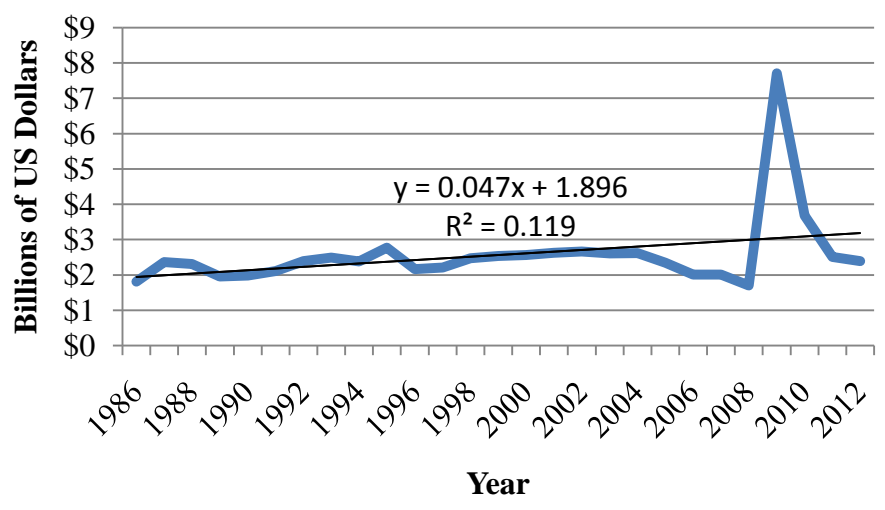

Figure 2. SRF allocations amounts and trend.

Since most non-debt capital comes from ratepayers, it is important to notice how the size of a utility can influence funding potential. A larger number of ratepayers can spread the burden out and help reduce the reliance on other funds. At the same time, however, utilities with larger populations to serve are typically in cities with infrastructure that was built decades ago, and may require larger amounts of capital. Regardless, smaller utilities are granted more funding through government programs than larger utilities for this reason.

External funding for water infrastructure projects has typically been obtained from government programs, such as those discusses in the above section, but there are several other non-traditional sources that could be considered. Private funds have been available, but many private investors have historically found water infrastructure inadequate in providing an acceptable return on their investment. There are several things that can be done to ease the hesitance of private investors, but there are also other sources of private funds that can be tapped to meet the private funding need in water infrastructure. These funds are private funds that are in investment tools already actively seeking reliable long-term investment options.

There are infrastructure funds across the globe seeking to invest in social infrastructure projects across a wide range of sectors, including the construction as well as operation and maintenance and management of core public infrastructure. A six-year period from 2007 to 2012 saw a rise in global infrastructure funds. In 2007, 47 funds had a target capital of $\$ 39$ billion. By 2012, 144 funds had a target capital of $\$ 93$ billion [6]. These funds have traditionally been geared towards highly visible projects such as schools, hospitals and government buildings, but can essentially incorporate transportation infrastructure and underground infrastructure as well. Fund managers would need to be made aware of the need and potential return on investment available through water and wastewater projects.

The most recent addition to the funding options available to water utilities is private funding. Private funding is not now, but using it for public services and utilities certainly is. The introduction exhibited examples of projects that included private participation, and based on their results it's obvious that they are not always successful. The reasons for misconceptions involving private funding are simply that the public, as well as government and utility decision makers, don't know enough about the options available to utilize in infrastructure projects. A simple comparison of public versus private funding source interests can be proposed as shown in Table 1.

\section{Public Private Partnerships}

The United States is behind the rest of the world when it comes to partnering with the private sector to provide water infrastructure. Since 1991, 814 water and sewer PPP projects, 334 of which were concessions, have been completed in low and middle-income countries [7]. Countries such Australia and Canada have policy in place to utilize PPP's. The largest issues with public private partnerships are lack of definition and lack of planning. There are various definitions of what a private-partnership actually is, but they all have the same main idea. The National Council for Public-Private Partnerships in the United States defines a PPP as "a contractual agreement between a public agency and a private sector entity" [8]. This is clearly a broad definition, and leaves much room for integrating more specific terms depending on the needs presented by each individual scenario. 
Table 1. Aspects of public and private capital.

\begin{tabular}{ccc}
\hline Key Aspects & Public Funding Source & Private Funding Source \\
\hline Motivation to Funding & Public Goods and Service & Business Opportunity \\
Ownership & Government/General Public & Shareholders \\
Source of Funds & Limited & Extensive \\
Financial Leverage Potential & Low & High \\
Profit from Investment & Little Concern & Most important \\
Regulation on Funding Sources and Structures & Very Strict & Less Strict \\
Cost of Financing & Lower & Higher \\
Range of Life Cycle & (If the Fund Is Public Tax Based) & Defined \\
New Technology Adoption & Not Defined & Adoptable \\
Project Delivery Method & Conservative & Flexible \\
(Efficiency) & Traditional & Adoptable \\
Human Resource Management & Traditional & Flexible \\
\hline
\end{tabular}

Because no two PPP projects are alike, there are countless forms a partnership can take. At one end of the spectrum, there are projects delivered traditionally by the public sector. At the other end, there is full privatization. A common misconception is that public-private partnerships are a form of privatization, which is not the case. Between traditional public procurement, and privatization, is where the wide spectrum of public-private partnerships is located.

A recent PPP project in water infrastructure is that of a private partner and Nassau County, NY. Nassau County selected the private partner to operate and maintain, as well as make improvements to improve wastewater treatment plants. The deal covers three treatment plants, 53 pumping stations, and over 3000 miles of pipe. The deal was scheduled to start in early 2013. The contract has a value of $\$ 700$ million [9].

The Indiana Toll Road featured a contract as a PPP concession agreement in which the government was paid an up-front payment of $\$ 3.8$ billion. The deal created an even partnership between two firms, as well as using senior bank debt from seven banks, backed by toll receipts. The concession was awarded to a project company, the Indiana Toll Road Concession Company, which is a partnership between the two private partners. The lease terms last a period of 75 years [10].

As mentioned in the introduction, the largest benefit of using private participation is the fact that it will help with the provision of funding resources. But the amount of funding resources required for completing a project, and how it can be affected by private partnerships is also an important factor. The private sector can generally provide skills and expertise not prevalent in the public sector, thus reducing the need for capital, rather than simply making it easier to obtain. Because of a more specialized skill set available to be applied in a partnership, the public can concentrate on what it is more capable of providing, while the private sector can bring necessary elements needed to reduce costs associated with individual infrastructure improvement projects.

The lifecycle of the typical water infrastructure system has several phases including: 1) planning; 2) financing; 3) design; 4) build; 5) operation and maintenance; 6) rehabilitation; and 7) close-out. At the end of the partnership, transfer is also a term that is included in a lot of PPP models, and one that can be a key difference between partnership contract types. Generally the above components of the typical infrastructure are in order of least to most private involvement. Design typically involves identifying the need for a project, as well as any development and planning work, and is generally included along with actually construction or rehabilitation work. The terms design and build are used standardly, and for consistency, but in many infrastructure projects planning and rehabilitation are more accurate substitutions. Finance involves providing funding to make the project a reality. Maintaining and operating the asset once construction or rehabilitation is complete can also be included in the partnership contract.

\section{Framework of PPP Models}

Figure 3 can be used as a guideline to illustrate available forms of funding that are appropriate for a typical 


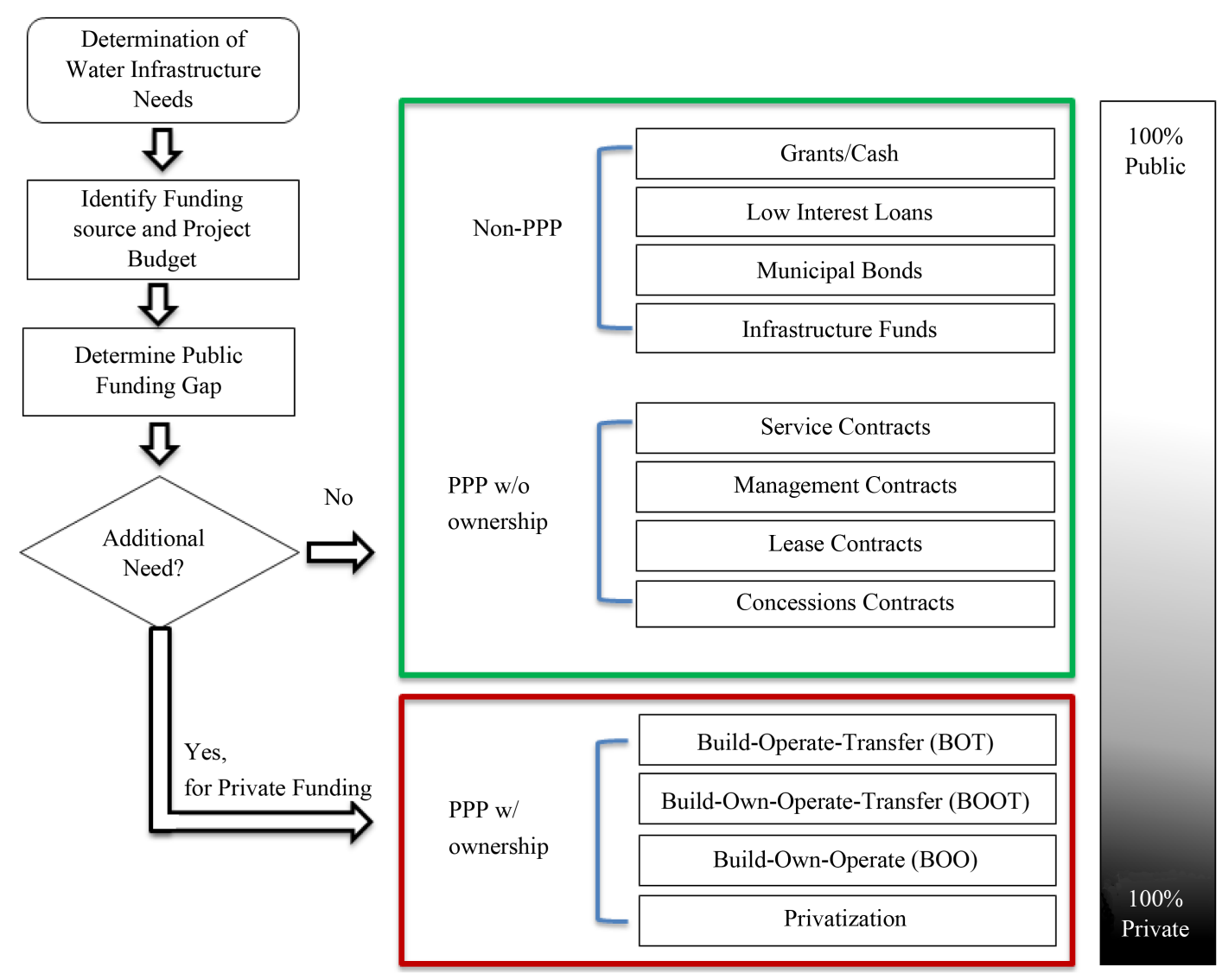

Figure 3. PPP model framework.

water infrastructure project in which private participation may require. The first step is to determine a project need, funding source, and budget. The second step should determine if the public owner recognizes alternative funding resources from potential private partners. A decision should be made if public funding is not sufficient. Figure 3 proposes three categories including non-PPP, PPP without private ownership, and PPP with private ownership.

Service Contracts represent the lowest level of private involvement. Contract out specific minor tasks (meter reading or billing), with little or no financial or ownership responsibilities going to the private sector. Management contracts actually transfer operations/maintenance or both to the private sector. (Assumes more risk and possible investment responsibility.) Usually paid by fixed fees (performance based) rather than unit prices. These are simple forms of partnership that require no transfers of ownership or much risk on the behalf of the private party.

Lease are generally contracts in which the private sector will maintain and operate the utility, but usually involves no private investment after the initial lump-sum lease payment. Leases generally cover mid- to long-term periods of time, making it easier to recover any large capital investments more efficiently. The private partner does not receive a fixed fee from the government, instead collecting fees from ratepayers. Some leases require the private operator to pay the government a portion of collected rates in addition to the fixed fee of the contract. This creates more risk, and greater pressure for efficiency in the hands of the private partner. Leases can include rate guarantees in the event they are unable to recoup necessary compensation during the extent of the lease.

Concession agreements are similar to leases except that capital investments can be financed by the private sector. The contract length for concessions is usually long term, even when compared to a lease contract. This is necessary in many cases to fully repay any large capital investments. Ownership of the infrastructure remains with the municipality but the private partner controls assets in the water system until the end of the concession period. Like leases, the private operator will collect fees from ratepayers.

BOT (Build-Operate-Transfer) occurs when the public sector contracts with the private sector to build (or re- 
habilitate), operate, and finance an individual assets construction or rehabilitation, instead of the whole system. The private party handles the operation until the contract expires, before transferring the responsibility back to the municipality. An important factor to note is that under a BOT contract, the private sector will not have a direct ownership stake in the project. Most BOT contracts can involve payments from the municipality because allocating costs of a specific asset can be more difficult, especially if it's a new asset without any revenue stream attributed to it, which is what sets a BOT contract apart from a standard concession agreement. A very similar setup to the BOT contract is a BOOT (Build-Own-Operate-Transfer) contract, with the obvious change being ownership. Under a BOOT model, the private party takes ownership of the asset or system covered by the lease. Adding ownership gives the private sector more incentive to invest, with a clear goal of recouping the initial investment costs as well as to turn a profit. A BOO (Build-Own-Operate) model sets up the partnership similarly to a BOOT contract, except that there is no predetermined transfer of ownership back to the public sector. This adds even more risk to the private parties ability to recover costs before asset is transferred. It also, however, gives the private sector the ability to recover any salvage value the asset may have. BOO contracts could, in fact, include a clause to end the contract after the assets life has passed.

\section{Conclusion}

The need for additional funding sources to address the rising infrastructure capital needs is obvious. While governments provide good sources of funding, there simply isn't enough money currently being allocated to rehabilitate and keep up with the growing need created by aging and growing infrastructure systems. The gap between the amount of capital currently available and the amount of capital needed for water infrastructure will continue to rise unless more effect measures are put in place to deal with it. The benefit of the public is forefront, and private capital can not only help alleviate the need for more public funding, but can in fact reduce the amount of capital needed through increased skills and expertise being brought into a project. Through discussing alternative forms of funding, specifically those involving the private sector, the hope is that the potential for public-private partnerships continues to be explored. By pointing out the potential ways in which alternatives to traditional infrastructure funding can help alleviate the funding gap, utilities can better understand the options they have.

\section{References}

[1] ASCE (2013) Report Card on America’s Infrastructure. American Society of Civil Engineers. http://www.infrastructurereportcard.org

[2] USEPA (2010) Clean Water Needs Survey 2008: Report to Congress. The United States Environmental Protection Agency. http://water.epa.gov/scitech/datait/databases/cwns/upload/cwns2008rtc.pdf

[3] ASCE (2011) Failure to Act: The Economic Impact of Current Investment Trends in Water and Wastewater Treatment Infrastructure. American Society of Civil Engineers. http://www.asce.org/failure_to_act_economic_studies/

[4] Food \& Water Watch (2010) United Water: Suez Environment’s Poor Record in the United States. http://documents.foodandwaterwatch.org/doc/SuezEngLR.pdf\#_ga=1.137542384.117171470.1420911785

[5] Black \& Veatch (2012) Strategic Directions in the U.S. Water Utility Industry. http://bv.com/docs/default-source/reports-studies/2012 water utility survey book web.pdf

[6] Prequin (2013) Global Infrastructure Trends in 2013. Global Infrastructure Investors Summit. https://www.preqin.com/item/2013-preqin-global-infrastructure-report/4/6129

[7] The World Bank (2012) Private Participation in Infrastructure Database. Public-Private Infrastructure Advisory Facility, Washington DC.

[8] National Council for Public-Private Partnerships (2013) Glossary of Terms. http://www.ncppp.org

[9] InfraPPP (2012) PPP for Operation \& Maintenance of Wastewater Treatment Assets for Nassau County. Infras PPP Databases. http://infrapppworld.com/infrastructure-funds

[10] GAO (2005) Highway and Transit Investments: Options for Improving Information on Projects' Benefits and Costs and Increasing Accountability for Results. United States Government Accountability Office. http://www.gao.gov/new.items/d05172.pdf 